INVITED REVIEW ARTICLE

\title{
肺がんの発症に関わる遺伝子多型
}

\author{
白石航也 1
}

\section{Genetic Polymorphisms and Susceptibility to Lung Cancer}

\author{
Kouya Shiraishi1 \\ ${ }^{1}$ Division of Genome Biology, National Cancer Center Research Institute, Japan.
}

ABSTRACT — Lung cancer is the leading cause of death in both men and women worldwide, and the 5-year survival rate for advanced lung cancer is as low as $20 \%$. The development of molecular-targeted cancer therapy has significantly improved the outcomes of non-small cell lung cancer (NSCLC) patients with epidermal growth factor receptor (EGFR) mutation and anaplastic lymphoma kinase (ALK) fusion oncogenes. In addition, immune checkpoint inhibitors have also dramatically changed the treatment regimens of NSCLC. From the viewpoint of cancer prevention, the prevalence of lung cancer in men is expected to decrease in the future due to smoking cessation efforts. As the smoking prevalence in women is already lower than that in men, the incidence of lung cancer in women is not expected to decrease quite as much as that in men. However, the therapeutic effect of immune checkpoint inhibitors in smokers with NSCLC can be expected, while such an effect in never-smokers with NSCLC is not expected. Because smoking is linked to the expression of neo-antigens and increased numbers of somatic mutations, immune checkpoint inhibitors in NSCLC have suggested the smoking history to be associated with improved survival outcomes. Therefore, the importance of determining the susceptibility to lung cancer in never-smokers, especially among women, is expected to increase in the future. In this review, the author describes the risk factors of susceptibility to lung cancer that have been identified thus far and the prospects for the future of cancer prevention.

(JJLC. 2018;58:331-337)

KEY WORDS — Genetic polymorphism, Lung cancer susceptibility gene, Genetic diversity of the HLA system

Corresponding author: Kouya Shiraishi.

要旨——肺がんは男女ともにがんの部位別死亡数の上 位を占める悪性腫瘍であり，進行肺がんの予後は $20 \%$ と極めて低い. しかし EGFR 体細胞変異をはじめとする ドライバー遺伝子変異に対する分子標的薬ならびに免疫 チェックポイント阻害剤の登場により, 非小細胞肺がん に対する治療法は大きな転換期を迎え，極めて予後不良 だった IV 期の進行肺がんの治癒も現実味を帯びてきて いる。一方肺がんの罹患率は, 禁煙の取り組みにより男 性肺がんにおいて今後減少が期待できる。しかしもとも と喫煙率が低い女性肺がんの発症数は, 男性に比べると 期待されるほど減少しないと考えられる。また喫煙者に 対する免疫チェックポイント阻害剂の治療効果は十分期
待されるが, 非契煙者特に女性非喫煙者肺がんでは EGFR 変異といったドライバー変異を伴う場合が多い. そのため, 免疫の惹起に関わる喫煙に依存するネオアン チゲンが認められないため, 免疫チェックポイント阻害 剤の恩恵が得られない可能性が指摘されている。した がって非喫煙者特に女性に対する肺がん発症要因の同定 は, 今後さらに重要性を増すと考えられる。本稿では, これまでに同定されてきた肺がんの発症リスク要因と今 後の研究の展望について述べる.

索引用語 一一遺伝子多型, 肺がん感受性遺伝子, HLA 遺伝子の多様性 


\section{今までに報告されている肺がんの発症に関わる外的 要因}

肺がんの主要組織型である腺がんは, 肺がんの危険因 子である能動契煙との関連が他の組織型（扁平上皮がん や小細胞肺がん, 大細胞肺がん)に比べて比較的弱く（相 対危険度は約 2 倍), また約半数は非契煙者で発症する. ${ }^{1}$ また近年日本人の非喫煙者を対象とした受動喫煙に対す るメタアナリシス研究による肺がんリスク評価が行わ れ，受動喫煙のある人はない人に比べて肺がんになるリ スクが約 1.3 倍となり, 国際的なメタアナリシスと同様 の結果が報告されている. ${ }^{2}$ また国立がん研究センター をはじめとする研究グループによる科学的根拠に基づい た『日本人のためのがん予防法』が報告されている。そ こには, 喫煙以外の肺がんの発症リスクとして,「肺結核 が可能性あり」,「職業性アスベストがほぼ確実」とされ ているが, 契煙以外の主要な肺がんリスク因子は明らか ではない. ${ }^{3}$ 一方で, 今までの報告で米国における若年の 肺がん罹患率は男性より女性で高いことが示唆されてい たが, この傾向は最近の出生コホート研究でも再現され ている. 4 しかしその発症要因は, 喫煙行動だけでは十分 説明ができていないことから, 環境要因によらない要因 が若年発症に寄与していると考えられる。またアジア人 では欧米人と比べて, 非契煙者, 特に女性において肺が んの発症割合が高く, 5 また腺がん組織中で認められる 体細胞変異頻度の分布は, 欧米人とアジア人で大きく異 なる. ${ }^{6}$ たとえば, EGFR 体細胞変異の頻度は欧米人に比 ベてアジア人で高く, 一方で $K R A S$ 体細胞変異頻度はア ジア人に比べて欧米人で高いことが知られている。 した がって肺がんの発症要因には人種差があり, 肺がん発症 には，契煙習慣や受動喫煙などによる環境要因や遺伝要 因が複合的に関与していると考えられる。このような遺 伝要因を同定するため, 一塩基多型（single nucleotide polymorphism : SNP) をマーカーとしたゲノム網羅的関 連解析 (genome-wide association study : GWAS) が多数 実施され，複数の肺がんリスクと関連するゲノム領域が 同定されている.

\section{遺伝要因からみる肺がん発症リスク因子}

ゲノム DNA の多様性は, 様々な疾患への罹患リスク マーカーとして用いられてきた. 以前は, SNPチップ データより得られる $5 \%$ 以上のコモンなバリアントもし くはSNPがリスクマーカーとして同定されてきたが, 近 年の次世代シークエンスの進歩により $1 \%$ 程度の頻度で 認められるレアなバリアントも同定されるようになっ た. また症例群と対照群の対象数, バリアントの頻度と オッズ比を基に算出される検出力により，同定できる真
の感受性遺伝子座の閾值が設定される. そのため, 多数 の真の感受性遺伝子座を同定するためには莫大なサンプ ル数を用いた解析が必要となり, 最近では数万例を対象 とした解析が一般的になってきている.

欧米のグループや我々を含めたアジアのグループに よって, 数千～数万例規模の肺がん患者と非がん対照集 団からなる GWAS が行われ, 複数の GWASによって再 現性が確認されている。 その代表的な肺がん感受性遺 伝子座として, CHRNA, 7,8 TERT, ${ }^{7-13}$ CLPTM1L, 7,8 TP 63, 8-10 BTNL 2, 10,11 FOXP 4-AS 1, 12,13 ROS 1, 8,11 VTI1A, 11,12 BPTF, 10,11 CYP2A6, 8,14 BRCA28,15 があり, Table 1 にまとめた.

欧米人を対象とした GWASにより，ニコチン性アセ チルコリン受容体サブユニットをコードするCHRNA 遺伝子群の多型は, 組織型や喫煙の有無によらず肺がん リスクとの関連が報告されている。 また CHRNA 遺伝子 とニコチン代謝に関わる CYP2A6 遺伝子の多型は, 喫煙 習慣と関連するとともに，肺がんリスクと喫煙習慣との 交互作用が報告されている。米国 NCI 主導で行われた, OncoArray Network プロジェクトの一環で行われた数 万人規模の肺がん患者を対象としたGWASにより，相 同組換えによる DNA 二本鎖切断の修復に重要な役割を 果たしているBRCA2 遺伝子のレアバリアントが, 扁平 上皮がんのリスク因子として同定された。しかしこれら のバリアントは, アジア人では認められていない欧米人 特異的なバリアントである。また扁平上皮がんとの関連 が認められた $B R C A 2$ 遺伝子のレアバリアントはタンパ ク質短縮を生じさせる変異であり, このバリアントは家 族性を含む乳がんや卵巣がん，皮䖉がん，消化管がんな ど多くのがんに対して発がんリスクと関連することが報 告されている. 15,16

テロメラーゼのサブユニットをコードする TERT 遺伝 子の多型は, 人種によらず腺がんリスクと関連する. TERT 遺伝子領域に近傍する CLPTM1L 遺伝子の多型 は，欧米人の腺がんや扁平上皮がんの他に中国人の非小 細胞肺がんでも発がんリスクとの関連が報告されてお り, 今後 TERT 遺伝子のバリアントと独立して発がんリ スクに寄与するか検討する必要がある. 17 興味深いこと に, TERT 遺伝子の多型は, 欧米人に比べてアジア人にお いて強く腺がんリスクと関連し (Table 1), アジア人肺腺 がんの半数を占める EGFR 変異陽性腺がんの方が $E G F R$ 変異陰性腺がんと比べてょり強くリスクに寄与すること が報告されている. 13 一方で，マウス実験による KRAS 変異を導入して発生した肺がんに対して, RNAiを用い て CLPTM1L 遺伝子の発現量を抑制すると発がん能が低 下したという報告がなされている. 18 したがって, ドラ イバー変異型によって TERT や CLPTM1L 遺伝子の寄与 
Table 1. Summary of Previously Reported Cases of GWAS with Lung Cancer Risk

\begin{tabular}{|c|c|c|c|c|c|c|c|c|c|}
\hline \multirow{2}{*}{$\begin{array}{l}\text { Chromo- } \\
\text { some } \\
\text { position }\end{array}$} & \multirow{2}{*}{ Gene symbol } & \multirow{2}{*}{ Gene name } & \multirow{2}{*}{$\begin{array}{c}\text { Strongest } \\
\text { SNP-risk allele }\end{array}$} & \multirow{2}{*}{ Location } & \multicolumn{2}{|c|}{$\begin{array}{l}\text { Frequency of } \\
\text { risk allele* }\end{array}$} & \multicolumn{2}{|c|}{ Odds ratio } & \multirow{2}{*}{$\begin{array}{l}\text { Association between } \\
\text { histological type and } \\
\text { lung cancer risk }\end{array}$} \\
\hline & & & & & EAS & EUR & Asian & Caucasian & \\
\hline $3 \mathrm{q} 28$ & TP63 & Tumor protein p63 & rs10937405-C & Intron & 0.689 & 0.572 & $1.23-1.31$ & 1.12 & $\begin{array}{l}\text { ADC, EGFR-mutated } \\
\text { ADC }\end{array}$ \\
\hline $5 \mathrm{p} 15.33$ & TERT & $\begin{array}{l}\text { Telomerase reverse } \\
\text { transcriptase }\end{array}$ & rs $2736100-\mathrm{G}$ & Intron & 0.415 & 0.499 & $1.27-1.46$ & $1.12-1.25$ & $\mathrm{ADC}$ \\
\hline $5 \mathrm{p} 15.33$ & CLPTM1L & CLPTM1-like & rs31489-C & Intron & 0.810 & 0.591 & - & $1.12-1.20$ & $\mathrm{ADC}, \mathrm{SQC}$ \\
\hline \multirow[t]{2}{*}{$6 \mathrm{p} 21.32$} & BTNL2 & Butyrophilin-like 2 & rs3817963-G & Intron & 0.231 & 0.276 & $1.18-1.29$ & - & $\mathrm{ADC}$ \\
\hline & $H L A-D P B 1$ & $\begin{array}{l}\text { Major histocompat- } \\
\text { ibility complex, class } \\
\text { II, DP beta } 1\end{array}$ & rs2179920-A & $\begin{array}{l}\text { Inter- } \\
\text { genic }\end{array}$ & 0.141 & 0.233 & 1.36 & - & EGFR-mutated ADC \\
\hline $6 \mathrm{p} 21.1$ & FOXP4-AS1 & $\begin{array}{c}\text { FOXP4 antisense } \\
\text { RNA } 1\end{array}$ & rs2495239-A & Intron & 0.429 & 0.086 & $1.18-1.19$ & - & $\begin{array}{l}\text { ADC, EGFR-mutated } \\
\text { ADC }\end{array}$ \\
\hline 6q22.1 & ROS1 & $\begin{array}{l}\text { ROS proto-oncogene } \\
1 \text {, receptor tyrosine } \\
\text { kinase }\end{array}$ & rs9387478-C & $\begin{array}{l}\text { Inter- } \\
\text { genic }\end{array}$ & 0.502 & 0.495 & 1.18 & 1.09 & $\mathrm{ADC}$ \\
\hline $10 \mathrm{q} 25.2$ & VTI1A & $\begin{array}{l}\text { Vesicle transport } \\
\text { through interaction } \\
\text { with t-SNAREs 1A }\end{array}$ & rs7086803-A & Intron & 0.294 & 0.028 & 1.28 & - & $\mathrm{ADC}$ \\
\hline 13q13.1 & $B R C A 2$ & $\begin{array}{l}\text { BRCA2, DNA repair- } \\
\text { associated }\end{array}$ & rs11571833-T & $\begin{array}{l}\text { Stop } \\
\text { gained }\end{array}$ & 0.000 & 0.011 & - & $1.60-2.47$ & SQC, SCC \\
\hline $15 q 25.1$ & CHRNA3 & $\begin{array}{l}\text { Cholinergic receptor } \\
\text { nicotinic alpha } 3\end{array}$ & rs1051730-T & $\begin{array}{l}\text { Synony- } \\
\text { mous }\end{array}$ & 0.027 & 0.369 & - & $1.31-1.35$ & $\mathrm{ADC}, \mathrm{SQC}, \mathrm{SCC}$ \\
\hline $17 \mathrm{q} 24.2$ & BPTF & $\begin{array}{l}\text { Bromodomain PHD } \\
\text { finger transcription } \\
\text { factor }\end{array}$ & rs7216064-A & Intron & 0.692 & 0.214 & $1.16-1.20$ & - & $\mathrm{ADC}$ \\
\hline $19 \mathrm{q} 13.2$ & CYP2A6 & $\begin{array}{c}\text { Cytochrome P450 } \\
\text { family } 2 \text { subfamily A } \\
\text { member } 6\end{array}$ & rs56113850-C & Intron & 0.340 & 0.592 & - & $1.12-1.16$ & $\mathrm{ADC}, \mathrm{SQC}$ \\
\hline
\end{tabular}

Asians and Caucasians have different genetic susceptibilities to lung cancer. Variants in CHRNA3, CYP2A6 and BRCA2 are strongly associated with lung cancer risk in Caucasians. Variants in TERT, TP63, ROS1 and HLA region are associated with lung cancer risk both in Asians and Caucasians. On the other hand, variants in BTNL2, FOXP4-AS1, VTI1A and BPTF are strongly associated with lung cancer risk in Asians.

*EAS, East Asia in 1000 genomes super population; EUR, Europe in 1000 genomes super population.

ADC, adenocarcinoma; SQC, squamous cell carcinoma; SCC, small cell carcinoma.

が異なる可能性も考えられる.

当初アジア人集団を対象とした GWASでのみ, p53 がん抑制遺伝子のファミリーに属するTP63 とインスリ ン受容体ファミリーの受容体チロシンキナーゼである ROS1 遺伝子が肺がん感受性遺伝子座として同定されて いたが，後に欧米人を対象としたGWASによりTP63 や ROS1 も肺がん感受性遺伝子として同定された。 しか し, 肺がんリスクへの寄与度は欧米人と比べてアジア人 で高い傾向を示しており，人種によって感受性遺伝子の 寄与度が異なると考えられる。またアジア人を対象に同 定された感受性遺伝子座としては, 免疫応答に関わる BTNL2 とFOXP4-AS1, ヌクレオソームリモデリング構 成因子である BPTF, 小胞輸送において膜融合に関わる $V T I 1 A$ が報告されている.

我々はEGFR 変異を伴う腺がんを対象とした全ゲノ ム関連解析を実施し, HLA クラス II 領域を含む 6 つの 感受性遺伝子座を同定している (Figure 1).さらに本稿
でも紹介する HLA imputation 法を用いることで, HLADPB1 タンパク質の 57 番目のアミノ酸の置換を起こす 多型が, EGFR 変異陽性の腺がん発症リスクに関わるこ とを見出している. 今後は, HLA アリルやアミノ酸の違 いにより免疫活性化能の違いがあるかを検討する必要が ある. 今回報告した肺がん感受性遺伝子の機能的意義は 未だ不明な部分が多く, 今後培養実験やがんゲノム解析 を通して，さらなる機能的な役割を明らかにする必要が ある。

また今までに報告したバリアントは, 個々のオッズ比 が 1.1〜 1.5 と低いものの, 効果サイズの推定值で重み付 けしたリスクアリル数の和を算出するポリジェニック・ スコアを算出することで, 遺伝的な発症リスク予測モデ ルを構築することができると考えられる。 これらの解析 手法を用いることで, 高リスク群を捕捉するための手段 の 1 つになると考えられる. 


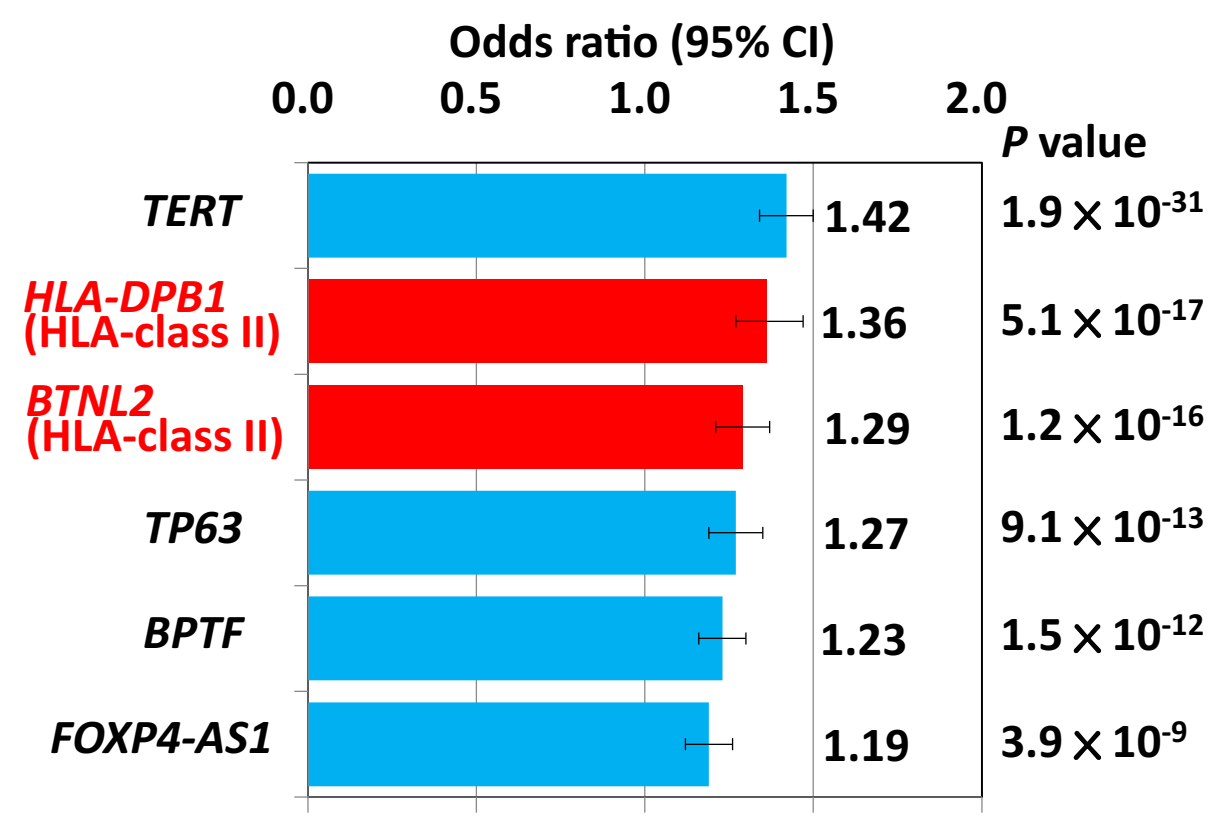

Figure 1. Association of six SNPs with the risk of lung adenocarcinoma with an EGFR mutation. Four loci-5p15.33 (TERT: rs2736100), and 6p21.3 (BTNL2: rs3817963), 3q28 (TP63: rs7636839), and 17q24.2 (BPTF: rs7216064)—previously shown to be strongly associated with the overall lung adenocarcinoma risk in East Asians were re-discovered as loci more strongly associated with the risk of lung adenocarcinomas with EGFR mutations than with those without such mutations. In addition, the loci HLA-class II at 6p21.32 (BTNL2: rs2179920) and 6p21.1 (FOXP4-AS1: rs2495239) were newly identified as being strongly associated with the overall lung adenocarcinoma risk in East Asians.

HLA（human leukocyte antigen）遺伝子領域の多様 性と肺がんリスクとの関連

先に述べた欧米人を対象としたGWASでもう1つ着 目すべき点として，扁平上皮がんにおいて HLA 領域に 多数の感受性遺伝子が同定されたことである (Table 2). しかし HLA 領域は非常に強い連鎖不平衡を形成するこ とから, Table 2 に示されているバリアントが全て独立 したリスク因子となり得るかについては，さらなる検証 が必要である. HLA は主に HLA クラス I (HLA-A, HLAB, HLA-C など) と HLA クラス II (HLA-DR, HLA-DQ, HLA-DP など)に分けられる. MHC (major histocompatibility complex）クラス I は，たとえば腫瘍細胞などから 産生される外来性抗原から細胞障害性 $\mathrm{T}$ 細胞への抗原 提示に用いられ，MHC クラス II は抗原提示細胞からへ ルパー T細胞への抗原提示に用いられる. 近年のがんゲ ノム解析により, 成人 $\mathrm{T}$ 細胞白血病・リンパ腫19 や非小 細胞肺がん20に扔いて, HLA 遺伝子の久失変異や久損な どが他の遺伝子よりも多く蓄積されており，がん免疫か らの回避に重要な役割を果たしていると考えられてい る.したがって肺がんの発症要因にも, HLAの多様性が 大きな影響を与えている可能性が考えられる.

\section{HLA 遺伝子型と免疫状態の推定}

HLA 遺伝子の多型は, その高度な多様性のため人種間 で大きく異なるため, HLA アリルの同定は非常に煩雑で あった。しかし近年のゲノム解析の進歩により, がん免 疫機構を解明するための 1 つの手法として, HLA アリル の推定やネオアンチゲン解析などが行われている. その ゲノム解析手法について簡単に概説する.

SNP チップデータをベースにした HLA 遺伝子型推定 アルゴリズム (HLA imputation)には, 主に SNP2HLA ${ }^{21}$ と $\mathrm{HIBAG}^{22}$ が知られて扔り, SNPチップデータがあれ ば, HLA アリルを推定することができる. 両ソフトウエ アの HLA アリルの推定精度はともに $90 \%$ 以上と高く, また日本人特異的なアリルやハプロタイプを含む日本人 参照データが既に構築されている。 また次世代シークエ ンスを用いた HLA 遺伝子型推定アルゴリズムは既に多 数報告されており, 主なアルゴリズムとして HLAminer, ${ }^{23}$ OptiType ${ }^{24}$ などが知られている. 報告さ れているアルゴリズムの精度評価により, HLA クラス I に限るとOptiType が, 最も精度よく HLA 遺伝子型を 推定できるとされている.

腫瘍特異的に発現した体細胞変異を伴うペプチド（ネ 
Table 2. Genetic Variants of the HLA Region Identified in GWAS in European and American Populations

\begin{tabular}{|c|c|c|c|c|c|c|c|c|}
\hline \multirow{2}{*}{$\begin{array}{l}\text { Chromosome } \\
\text { position }\end{array}$} & \multirow{2}{*}{$\begin{array}{l}\text { Gene } \\
\text { symbol }\end{array}$} & \multirow{2}{*}{ Gene name } & \multirow{2}{*}{$\begin{array}{l}\text { Strongest SNP- } \\
\quad \text { risk allele }\end{array}$} & \multirow{2}{*}{ Location } & \multicolumn{2}{|c|}{$\begin{array}{l}\text { Frequency of risk } \\
\text { allele* }\end{array}$} & \multirow{2}{*}{$\begin{array}{l}\text { Odds } \\
\text { ratio }\end{array}$} & \multirow{2}{*}{$\begin{array}{l}\text { Association between } \\
\text { histological type and } \\
\text { lung cancer risk }\end{array}$} \\
\hline & & & & & EAS & EUR & & \\
\hline $6 \mathrm{p} 22.2$ & $B T N 3 A 2$ & $\begin{array}{c}\text { Butyrophilin subfamily } 3 \\
\text { member A2 }\end{array}$ & rs34107459-C & $\begin{array}{l}\text { Regulatory } \\
\text { region }\end{array}$ & 0.000 & 0.067 & 1.26 & $\mathrm{SQC}$ \\
\hline $6 \mathrm{p} 22.1$ & PRSS16 & Serine protease 16 & rs35768595-T & Intergenic & 0.000 & 0.069 & 1.24 & $\mathrm{SQC}$ \\
\hline $6 \mathrm{p} 22.1$ & $H L A-A$ & $\begin{array}{l}\text { Major histocompatibility } \\
\text { complex, class I, A }\end{array}$ & rs147097402-A & Intron & ND & ND & 1.25 & $\mathrm{SQC}$ \\
\hline 6p21.33 & $H L A-C$ & $\begin{array}{l}\text { Major histocompatibility } \\
\text { complex, class I, C }\end{array}$ & rs115390513-C & Intergenic & 0.000 & 0.087 & 1.26 & $\mathrm{SQC}$ \\
\hline $6 \mathrm{p} 22.1$ & $H L A-E$ & $\begin{array}{l}\text { Major histocompatibility } \\
\text { complex, class I, E }\end{array}$ & rs116310021-G & Intergenic & 0.000 & 0.080 & 1.27 & SQC \\
\hline $6 \mathrm{p} 22.1$ & $H L A-G$ & $\begin{array}{l}\text { Major histocompatibility } \\
\text { complex, class I, G }\end{array}$ & rs116506680-T & Intergenic & 0.340 & 0.439 & 1.10 & $\mathrm{ADC}$ \\
\hline $6 \mathrm{p} 21.32$ & $H L A-D Q A 1$ & $\begin{array}{c}\text { Major histocompatibility } \\
\text { complex, class II, DQ } \\
\text { alpha } 1\end{array}$ & rs74942078-A & Intron & 0.052 & 0.106 & 1.27 & $\mathrm{SQC}$ \\
\hline $6 \mathrm{p} 21.32$ & $H L A-D Q B 2$ & $\begin{array}{c}\text { Major histocompatibility } \\
\text { complex, class II, DQ } \\
\text { beta } 2\end{array}$ & rs148861668-T & Intergenic & 0.000 & 0.084 & 1.22 & $\mathrm{SQC}$ \\
\hline
\end{tabular}

McKay et al reported that variants in HLA region were associated with risk to lung squamous cell carcinoma in Caucasians. On the other hand, Shiraishi et al reported that variants in HLA region, including BTNL2 and HLA-DPB1, were associated with lung adenocarcinoma risk in Asians.

*EAS, East Asia in 1000 genomes super population; EUR, Europe in 1000 genomes super population.

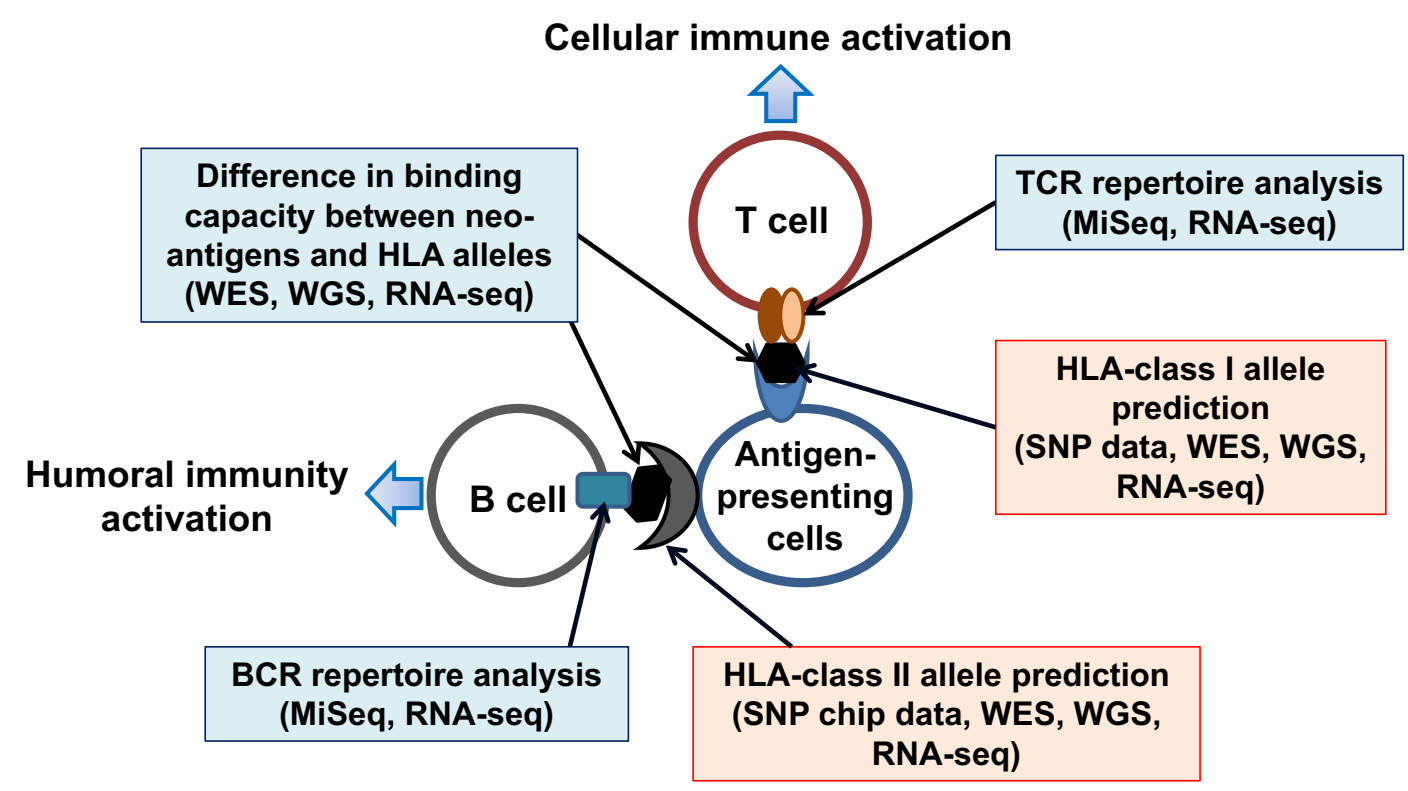

Figure 2. Overview of the neo-antigen landscape and identification strategies using next-generation sequencing. To predict each individual's HLA alleles, HLA imputation is performed using SNP chip data, whole-exome sequencing (WES), whole-genome sequencing (WGS) or RNA sequencing (RNA-seq). $\mathrm{T}$ cell receptor (TCR) and $\mathrm{B}$ cell receptor $(\mathrm{BCR})$ repertoire analyses are useful for evaluating the diversity of a patient's immune system. To predict the binding capacity between neo-antigens and HLA alleles, some analyses are performed using WES, WGS and RNA-seq.

オアンチゲン)が MHC に提示されると, 腫瘍特異的な免 疫を誘導される。よってネオアンチゲンの多様性を評価 することは，個々人の免疫状態を明らかにするために必
要な解析である. ネオアンチゲンを同定するために, $\mathrm{MHC}$ クラス I と変異ペプチドとの結合能を推定するア ルゴリズムが多数報告されており（Figure 2), 主に 
NetMHCpan, ${ }^{25}$ NetCTLpan 26 などが知られている. 具 体的には, 全エクソンシークエンスなどで認められたア ミノ酸変化を伴うバリアント情報を基にエピトープを推 定し，さらに immune epitope database（IEDB）による ニューラルネットワークなどのデータ解析技術を組み合 わせることで, MHC クラス I とネオアンチゲンとの結合 親和性を推定する.一方 Neopepsee ${ }^{27}$ は, 腫瘍と非がん組 織検体由来 DNA を用いた全エクソンシークエンスデー 夕などを基に変異ぺプチドを推定するとともに，RNAseq により実際にがん組織中で発現しているネオアンチ ゲンに絞って解析する方法である。また MHCクラス II へのペプチドの結合能の推定には, NetMHCII が最も精 度が高いと言われている。しかし, MHCクラス II に結合 する変異ぺプチドの長さは, MHC クラス I に比べて厳格 に規定されていないためアルゴリズムの推定が難しく， $\mathrm{MHC}$ クラス I と II ともに培養実験などを用いた生物学 的な検証が必須である。

免疫システムはネオアンチゲンの多様性に対応するた め, $\alpha \beta \mathrm{T}$ 細胞受容体 $(\mathrm{T}$ cell receptor : $\mathrm{TCR}$ ) ・ B 細胞受 容体 (B cell receptor : BCR) 遺伝子や免疫グロブリン遺 伝子を再構成することで，抗原多様性に対処している. MHC が提示した抗原と結合する相補性決定領域（complementarity determining region : CDR）では無作為に 塩基の欠失や挿入が発生することで，抗原認識に対して 多様性を持たせている，TCR/BCR 遺伝子配列を網羅的 に調べることで, 疾患に関連する $\mathrm{T}$ 細胞や $\mathrm{B}$ 細胞の同定 につながるとともに, TCR を通してどのような抗原を認 識し, 腫瘍細胞に対して免疫を誘導しているか免疫系の 多様性を評価するためにも有用である. TCR レパトア解 析は, CDR をロングリードでシークエンスする必要があ り，それに対応可能な次世代シークエンサー（Illumina 製 MiSeq など)を用いて行われる. 一方で, RNA シーク エンスといった次世代シークエンスなどを用いた推定ア ルゴリズムが開発されており, MiXCR, 28 MIGEC 29 やそ の後の解析ッールとしての VDJtools 30 が知られている. しかしまだこれらのアルゴリズムに対して，異なるサン プルセットを用いた精度評価がなされていないため, 実 際に免疫応答が惹起されるかについてはさらなる生物学 的な検証実験が必要である.

\section{今後の展望}

近年のゲノム解析により, 多数の肺がん感受性遺伝子 座が同定できるようになった。しかし当初期待されてい たような高精度の肺がん高危険度群の捕捉には未だ至っ ていない. その原因としては, 同定されたリスクアリル がオッズ比 $1.1 〜 1.5$ 程度と低いことと, 契煙をはじめと する環境要因が複合的に関与しているためと考えられ
る.今後はより疫学的な側面を含めた, たとえば喫煙依 存的な発がんリスク要因の同定, 非喫煙者における受動 契煙による発がんリスクに寄与する遺伝要因の同定が重 要になると考えられる。またがんゲノム解析により, HLA の失活が発がんに重要な役割を果たしているとい う報告がなされており，今後 HLAに着目した発がん機 構を解明する必要がある。したがって, 肧細胞系列変異 の他に体細胞変異や生活習慣情報を組み合わせて解析す ることが重要であり, 既に取得されている大規模ゲノム 情報の統合解析が, プレシジョン・メディシンを推進す る上で有益なツールとなり得る.

本論文内容に関連する著者の利益相反：なし

\section{REFERENCES}

1. Sobue T, Suzuki T, Fujimoto I, Matsuda M, Doi O, Mori $\mathrm{T}$, et al. Case-control study for lung cancer and cigarette smoking in Osaka, Japan: comparison with the results from Western Europe. Jpn J Cancer Res. 1994;85:464-473.

2. Hori M, Tanaka H, Wakai K, Sasazuki S, Katanoda K. Secondhand smoke exposure and risk of lung cancer in Japan: a systematic review and meta-analysis of epidemiologic studies. Jpn J Clin Oncol. 2016;46:942-951.

3. Sasazuki S, Inoue M, Shimazu T, Wakai K, Naito M, Nagata C, et al. Evidence-based cancer prevention recommendations for Japanese. Jpn J Clin Oncol. 2018;48:576586.

4. Jemal A, Miller KD, Ma J, Siegel RL, Fedewa SA, Islami $\mathrm{F}$, et al. Higher Lung Cancer Incidence in Young Women Than Young Men in the United States. $N$ Engl $J$ Med. 2018;378:1999-2009.

5. Thun MJ, Hannan LM, Adams-Campbell LL, Boffetta P, Buring JE, Feskanich D, et al. Lung cancer occurrence in never-smokers: an analysis of 13 cohorts and 22 cancer registry studies. PLoS Med. 2008;5:e185.

6. Kohno T, Nakaoku T, Tsuta K, Tsuchihara K, Matsumoto S, Yoh K, et al. Beyond ALK-RET, ROS1 and other oncogene fusions in lung cancer. Transl Lung Cancer Res. 2015;4:156-164.

7. Landi MT, Chatterjee N, Yu K, Goldin LR, Goldstein AM, Rotunno M, et al. A Genome-wide Association Study of Lung Cancer Identifies a Region of Chromosome 5p15 Associated with Risk for Adenocarcinoma. Am J Hum Genet. 2011;88:861.

8. McKay JD, Hung RJ, Han Y, Zong X, Carreras-Torres R, Christiani DC, et al. Large-scale association analysis identifies new lung cancer susceptibility loci and heterogeneity in genetic susceptibility across histological subtypes. Nat Genet. 2017;49:1126-1132.

9. Miki D, Kubo M, Takahashi A, Yoon KA, Kim J, Lee GK, et al. Variation in TP63 is associated with lung adenocarcinoma susceptibility in Japanese and Korean populations. Nat Genet. 2010;42:893-896.

10. Shiraishi K, Kunitoh H, Daigo Y, Takahashi A, Goto K, Sakamoto $\mathrm{H}$, et al. A genome-wide association study 
identifies two new susceptibility loci for lung adenocarcinoma in the Japanese population. Nat Genet. 2012;44:900903.

11. Lan Q, Hsiung CA, Matsuo K, Hong YC, Seow A, Wang $Z$, et al. Genome-wide association analysis identifies new lung cancer susceptibility loci in never-smoking women in Asia. Nat Genet. 2012;44:1330-1335.

12. Wang Z, Seow WJ, Shiraishi K, Hsiung CA, Matsuo K, Liu J, et al. Meta-analysis of genome-wide association studies identifies multiple lung cancer susceptibility loci in never-smoking Asian women. Hum Mol Genet. 2016;25: 620-629.

13. Shiraishi K, Okada Y, Takahashi A, Kamatani Y, Momozawa Y, Ashikawa K, et al. Association of variations in HLA class II and other loci with susceptibility to EGFR-mutated lung adenocarcinoma. Nat Commun. 2016;7:12451.

14. Thorgeirsson TE, Gudbjartsson DF, Surakka I, Vink JM, Amin N, Geller F, et al. Sequence variants at CHRNB3CHRNA 6 and CYP 2 A 6 affect smoking behavior. Nat Genet. 2010;42:448-453.

15. Wang Y, McKay JD, Rafnar T, Wang Z, Timofeeva MN, Broderick P, et al. Rare variants of large effect in BRCA2 and CHEK2 affect risk of lung cancer. Nat Genet. 2014;46: 736-741.

16. Meeks HD, Song H, Michailidou K, Bolla MK, Dennis J, Wang Q, et al. BRCA2 Polymorphic Stop Codon K3326X and the Risk of Breast, Prostate, and Ovarian Cancers. $J$ Natl Cancer Inst. 2015;108. pii: djv315.

17. Hu Z, Wu C, Shi Y, Guo H, Zhao X, Yin Z, et al. A genome-wide association study identifies two new lung cancer susceptibility loci at $13 \mathrm{q} 12.12$ and $22 \mathrm{q} 12.2$ in Han Chinese. Nat Genet. 2011;43:792-796.

18. James MA, Vikis HG, Tate E, Rymaszewski AL, You M. CRR9/CLPTM1L regulates cell survival signaling and is required for Ras transformation and lung tumorigenesis. Cancer Res. 2014;74:1116-1127.

19. Kataoka K, Nagata Y, Kitanaka A, Shiraishi Y, Shimamura T, Yasunaga J, et al. Integrated molecular analysis of adult T cell leukemia/lymphoma. Nat Genet. 2015;47:1304-1315.

20. McGranahan N, Rosenthal R, Hiley CT, Rowan AJ,
Watkins TBK, Wilson GA, et al. Allele-Specific HLA Loss and Immune Escape in Lung Cancer Evolution. Cell. 2017;171:1259-1271.e11.

21. Okada Y, Momozawa Y, Ashikawa K, Kanai M, Matsuda $\mathrm{K}$, Kamatani $\mathrm{Y}$, et al. Construction of a populationspecific HLA imputation reference panel and its application to Graves' disease risk in Japanese. Nat Genet. 2015; 47:798-802.

22. Khor SS, Yang W, Kawashima M, Kamitsuji S, Zheng X, Nishida N, et al. High-accuracy imputation for HLA class I and II genes based on high-resolution SNP data of population-specific references. Pharmacogenomics J. 2015; 15:530-537.

23. Warren RL, Choe G, Freeman DJ, Castellarin M, Munro $\mathrm{S}$, Moore R, et al. Derivation of HLA types from shotgun sequence datasets. Genome Med. 2012;4:95.

24. Szolek A, Schubert B, Mohr C, Sturm M, Feldhahn M, Kohlbacher O. OptiType: precision HLA typing from next-generation sequencing data. Bioinformatics. 2014;30: 3310-3316.

25. Hoof I, Peters B, Sidney J, Pedersen LE, Sette A, Lund O, et al. NetMHCpan, a method for MHC class I binding prediction beyond humans. Immunogenetics. 2009;61:1-13.

26. Stranzl T, Larsen MV, Lundegaard C, Nielsen M. NetCTLpan: pan-specific MHC class I pathway epitope predictions. Immunogenetics. 2010;62:357-368.

27. Kim S, Kim HS, Kim E, Lee MG, Shin EC, Paik S, et al. Neopepsee: accurate genome-level prediction of neoantigens by harnessing sequence and amino acid immunogenicity information. Ann Oncol. 2018;29:1030-1036.

28. Bolotin DA, Poslavsky S, Mitrophanov I, Shugay M, Mamedov IZ, Putintseva EV, et al. MiXCR: software for comprehensive adaptive immunity profiling. Nat Methods. 2015;12:380-381.

29. Melnik S, Caudron-Herger M, Brant L, Carr IM, Rippe K, Cook PR, et al. Isolation of the protein and RNA content of active sites of transcription from mammalian cells. Nat Protoc. 2016;11:553-565.

30. Shugay M, Bagaev DV, Turchaninova MA, Bolotin DA, Britanova OV, Putintseva EV, et al. VDJtools: Unifying Post-analysis of T Cell Receptor Repertoires. PLoS Comput Biol. 2015;11:e1004503. 